DOI: http://dx.doi.org/10.33846/ghs6109

\title{
Peran Petugas Kesehatan dan Ketersediaan Air Bersih dalam Kepemilikan Jamban di Kampung Wainlabat Kabupaten Sorong
}

\author{
Jenni Lilis. S. Siagian (koresponden) \\ Program Studi Kesehatan Masyarakat, Sekolah Tinggi IImu Kesehatan Papua; \\ siagianjennililis@gmail.com \\ Hansen Maikel Su \\ Program Studi IImu Keperawatan, Sekolah Tinggi IImu Kesehatan Papua; \\ hansenmaikelsu77@gmail.com
}

\begin{abstract}
ABSTRAK
Ketersediaan jamban yang baik dikeluarga dapat memberikan dampak positif yakni meningkatkan status kesehatan masyarakat dan dampak negatifnya adalah menjadi sumber penularan penyakit infeksi. Tujuan penelitian adalah menganalisis hubungan peran petugas kesehatan dan ketersediaan air bersih dengan kepemilikan jamban di Kampung Wainlabat Kabupaten Sorong. Jenis penelitian ini adalah deskriptif analitik dengan pendekatan cross sectional. Populasi penelitian adalah seluruh kepala keluarga di Kampung Wainlabat sebanyak $42 \mathrm{KK}$, sampel diambil dengan menggunakan teknik total sampling. Data dikumpulkan dengan menggunakan kuesioner dan lembar observasi. Analisis data menggunakan uji Chi square. Hasil penelitian diperoleh responden dengan ketersediaan air bersih baik sebanyak 5 orang $(11,9 \%)$, peran petugas kesehatan baik sebanyak 8 orang $(19,0 \%)$ dan jumlah kepemilikan jamban yang memenuhi sebanyak 19 orang $(45,2 \%)$. Peran petugas kesehatan nilai $p=0,474>\alpha(0,05)$ artinya tidak ada hubungan peran petugas kesehatan dengan kepemilikan jamban, dan ketersediaan air bersih nilai $p=0,005<\alpha(0,05)$ artinya ada hubungan ketersediaan air dengan kepemilikan jamban. Disimpulkan ada hubungan ketersediaan air bersih dengan kepemilikan jamban di Kampung Wainlabat Kabupaten Sorong dan tidak ada hubungan peran petugas kesehatan dengan kepemilikan jamban di Kampung Wainlabat Kabupaten Sorong.

Kata kunci: jamban; pengetahuan; peran petugas kesehatan
\end{abstract}

\section{PENDAHULUAN}

Pemerintah Indonesia melalui Kementerian Kesehatan saat ini menjadikan program Sanitasi Total Berbasis Masyarakat (STBM), program ini telah menjadi kebijakan nasional. Tujuan daripada STBM ini adalah adalah diharapkan adanya peningkatan kemampuan dan perilaku hidup bersih dan sehat masyarakat dalam upaya mencegah terjadinya penyebaran penyakit yang berbasis lingkungan dan peningkatan akses air minum dan sanitasi dasar. STBM terdiri dari lima pilar yakni Stop buang air besar sembarangan, Cuci tangan pakai sabun, Pengolahan air minum dan makanan rumah tangga, pengamanan sampah rumah tangga dan pengamanan limbah cair rumah tangga. ${ }^{(1)}$ Upaya untuk mengurangi kebiasaan buang air besar sembarangan adalah menyediakan serta meningkatkan pemeliharaan sarana buang air besar seperti jamban yang memadai dan sesuai dengan ketentuan syarat kesehatan.

Ketersediaan jamban dengan baik dapat menghindari atau mengurangi terjadinya penyakit menular yang disebabkan oleh tinja. Penyediaan jamban ini termasuk dalam satu dari 17 agenda Tujuan Pembangunan Berkelanjutan (SDGs) tahun 2030, yakni agenda nomor 6 meningkatkan penyediaan air bersih dan sanitasi. (2) Menurut Unicef(3) di Indonesia terdapat sekitar 25 juta orang yang tidak memiliki toilet, dan $25 \%$ dari anak balita menderita diare dan menjadi penyebab kematian.

Tahun 2018 diketahui di Indonesia, jumlah penderita diare sebanyak 1.017.290 kasus sedangkan di Provinsi Papua Barat sebanyak 3.588 kasus yang menyerang berbagai kelompok usia, proporsi yang menggunakan jamban dengan benar sebesar 962.045 orang dan di Provinsi Papua Barat sebesar 3.341 orang. ${ }^{(4)}$ Jumlah masyarakat pengguna jamban sehat sekitar 62.3 juta.(5) Kabupaten Sorong, diketahui proporsi penanganan tinja kurang baik sebesar 49,64\% dan jumlah kasus diare sebanyak 1.262 kasus. ${ }^{(6)}$

Keluarga sehat adalah keluarga yag kepemilikan jamban sehat karena akan terhindar dari beberapa penyakit yang timbul akibat kotoran seperti kontaminasi zat racun, gangguan saluran pencernaan dan infeksi kecacingan, dan penyakit virus seperti hepatitis. Terdapat beberapa faktor yang memengaruhi kepemilikan jamban rumah tangga yang benar seperti pendidikan, tingkat ekonomi, pengetahuan, sikap dan budaya ${ }^{(7)}$, ketersediaan air bersih ${ }^{(8)}$, peran tokoh masyarakat dan peran petugas kesehatan. ${ }^{(9)}$ 
Berdasarkan data yang diperolah dari pihak terkait dari $42 \mathrm{KK}$ terdapat jamban permanen sebanyak 5 unit, jamban cemplun 19 unit dan 18 unit plesengan. Jumlah kasus diare tahun 2019 sebanyak 30 orang yang terjadi pada anak-anak dan dewasa. Tujuan pelaksanaan penelitian ini adalah menganalisis hubungan peran petugas kesehatan dan ketersediaan air bersih dengan kepemilikan jamban di Kampung Wainlabat Kabupaten Sorong.

\section{METODE}

Metode penelitian ini adalah kuantitatif yakni deskriptif analitik dengan rancangan cross sectional. Penelitian dilaksanakan di Kampung Wainlabat Distrik Seigun Kabupaten Sorong pada Maret 2020. Populasi penelitian ini adalah seluruh kepala keluarga di Kampung Wainlabat sebanyak $42 \mathrm{KK}$ dengan sampel sebanyak 42 orang. Data dikumpulkan dengan menggunakan kuesioner untuk data karakteristik responden dan variabel peran serta petugas kesehatan serta lembar observasi untuk variabel ketersediaan air bersih dan kepemilikan jamban. Data yang dikumpulkan dianalisis dengan menggunakan uji Chy square dan $\alpha=0,05$.

\section{HASIL}

Tabel 1. Distribusi frekuensi responden berdasarkan karakteristik di Kampung Wainlabat Kabupaten Sorong $(n=42)$

\begin{tabular}{|c|c|c|}
\hline Karakteristik & Frekuensi (f) & Persentase (\%) \\
\hline Umur & & 7,1 \\
\hline$\leq 26$ tahun & 3 & 52,4 \\
\hline $27-49$ tahun & 22 & 19,1 \\
\hline $50-59$ tahun & 8 & 21,4 \\
\hline$\geq 60$ tahun & 9 & \\
\hline Pendidikan & 28 & 66,7 \\
\hline SD sederajat & 6 & 14,3 \\
\hline SMP sederajat & 8 & 19,0 \\
\hline SMA sederajat & & \\
\hline Pekerjaan & 26 & 61,9 \\
\hline Tani & 4 & 9,6 \\
\hline Wiraswasta & 5 & 11,9 \\
\hline Buruh/ tukang & 7 & 16,6 \\
\hline Nelayan & & \\
\hline
\end{tabular}

Tabel 1 menunjukkan bahwa responden paling banyak adalah umur 27-49 tahun yakni sebanyak 22 orang $(52,4 \%)$, mayoritas berpendidikan SD sederajat yakni sebanyak 28 orang $(66,7 \%)$, serta pekerjaan bertani sebanyak 26 orang $(61,9 \%)$.

Tabel 2. Tabulasi silang ketersediaan air dan peran petugas kesehatan dengan kepemilikan jamban di Kampung Wainlabat Kabupaten Sorong $(n=42)$

\begin{tabular}{|c|c|c|c|c|c|}
\hline \multirow{2}{*}{ Variabel } & \multicolumn{4}{|c|}{ Kepemilikan jamban } & \multirow{2}{*}{ p-value } \\
\cline { 2 - 5 } & Memenuhi & \multicolumn{2}{|c|}{ Tidak memenuhi } & \multirow{2}{*}{} \\
\cline { 2 - 5 } & $\mathrm{f}$ & $\%$ & $\mathrm{f}$ & $\%$ & \\
\hline Peran petugas kesehatan & & & & & \\
\hline Baik & 8 & 19,0 & 9 & 21,4 & \\
\hline Kurang baik & 11 & 26,3 & 14 & 33,3 & 0,474 \\
\hline Ketersediaan air bersih & & & & & \\
\hline Memenuhi & 14 & 33,3 & 12 & 25,6 & 0,005 \\
\hline Tidak memenuhi & 5 & 11,9 & 11 & 26,2 & \\
\hline
\end{tabular}

Berdasarkan hasil tabulasi silang diketahui responden dengan peran petugas kesehatan baik yang kepemilikan jamban memenuhi syarat sebanyak 8 orang $(19,0 \%)$, sedangkan peran kurang baik yang kepemilikan jamban memenuhi syarat sebanyak 11 orang $(26,3 \%)$. Dan diperoleh nilai $p=0,474$ $>\alpha=0,05$ maka disimpulkan tidak ada hubungan peran petugas kesehatan dengan kepemilikan 
jamban di Kampung Wainlabat Kabupaten Sorong. Hasil tabulasi silang variabel ketersediaan air diperoleh dengan ketersediaan air memenuhi syarat yang kepemilikan jamban memenuhi sebanyak 14 orang $(33,3 \%)$ sedangkan responden yang tidak memenuhi syarat dengan kepemilikan jamban memenuhi syarat sebanyak 5 orang $(11,9 \%)$. Nilai $p=0.005<\alpha=0,05$ yang artinya ada hubungan ketersediaan air bersih dengan kepemilikan jamban di Kampung Wainlabat Kabupaten Sorong.

\section{PEMBAHASAN}

Hasil penelitian didapat jumlah responden dengan ketersediaan air bersih yang kepemilikan jamban tidak memenuhi syarat lebih banyak dibandingkan dengan memenuhi syarat, dan hasil analisa data diketahui bahwa ada hubungan ketersediaan air dengan kepemilikan jamban di Kampung Wainlabat Kabupaten Sorong. Artinya keluarga yang memiliki ketersediaan air bersih dengan baik, maka akan memiliki ketersediaan jamban yang baik, demikian sebaliknya keluarga dengan ketersediaan air bersih tidak baik akan memilki ketersediaan jamban yang kurang baik.

Jamban atau yang biasa disebut sebagai kakus merupakan suatu bangunan yang dipergunakan oleh masyarakat untuk membuang kotoran atau tinja yang disediakan untuk keluarga maupun masyarakat umum ditempatkan di dalam rumah maupun luar rumah namun prinsip penggunaannya terjangkau dengan mudah oleh pengguna. jamban yang sehat yakni bangunan yang memenuhi syarat dan standar kesehatan yang telah ditetapkan yakni bangunan bawah, tengah dan atas jamban. (1) Sehingga disimpulkan jamban yang sehat dapat memutus rantai penularan penyakit secara efektif, itu sebabnya jamban sudah menjadi salah satu bagian dari kebutuhan pokok manusia. Hubungan antara jamban dengan status kesehatan dapat diperoleh secara langsung yakni berkurangnya kejadian sakit penyakit akibat kontaminasi dengan tinja dan tidak langsung adalah buruknya hygiene lingkungan tinggal.

Faktor yang dapat memengaruhi kepemilikan jamban adalah ketersediaan air bersih, ${ }^{(10)}$ sejalan dengan penelitian yang dilakukan di Desa Walikukun Kecamatan Carenang Kabupaten Serang, sebagian besar masyarakat tidak memiliki jamban yang memenuhi syarat sehingga berdasarkan hasil uji diketahui bahwa ada hubungan ketersediaan air bersih dengan kepemilikan jamban ${ }^{(8)}$ dan penelitian yang dilakukan di Desa Semerah Kecamatan Sitinjau Kabupaten Kerinci, mengemukakan sebagian besar masyarakat dengan ketersediaan air yang tidak memenuhi syarat atau tidak baik, dan diperoleh ada hubungan ketersediaan air dengan kepemilikan jamban. ${ }^{(11)}$

Wilayah Kampung Wainlabat jauh dari perkotaan dan berada tengah hutan, dan dekat dengan laut. Untuk memenuhi kebutuhan air bersih sehari-hari, masyarakat menggunakan air tanah yang dibor dengan kedalaman sekitar 20-80 meter. Meskipun air tanah dibor cukup dalam namun secara syarat fisik air tersebut tidak memenuhi karena air tersebut berasa, berbau dan berwarna kuning. Pada musim hujan masyarakat menggunakan bantuan air hujan sebagai salah satu sumber air bersih.

Mayoritas masyarakat telah memiliki jamban namun yang tersedia belum memenuhi syarat kesehatan, seperti jamban plengsengan dan cemplung tanpa menggunakan septic tank hanya mengandalkan kolam dan tanah miring sebagai tempat penampungan tinja, sehingga daerah tersebut sering tercium bau tidak sedap. Dinding jamban terbuat dari papan atau seng yang sudah lapuk dengan lantai tanah. Untuk memenuhi kepemilikan jamban yang sehat maka masyarakat harus memperhatikan Ventilasi yang cukup, jarak lubang penampung dengan sumber air minum berjarak 10-15 meter, bangunan cukup luas dan landai sehingga tidak mencemari wilayah sekitar, mudah dibersihkan dan aman digunakan, memiliki atap pelindung, dinding dan lantai kedap air, tersedianya penerangan dan ventilasi yang cukup.

Asumsi peneliti ketersediaan air bersih yang tidak baik ini menyebabkan masyarakat menjadi kurang memperhatikan pentingnya kepemilikan jamban tersebut. Ketersediaan air bersih dapat memengaruhi kondisi jamban yang tersedia, misalnya air yang berwarna dan berbau jika digunakan untuk membersihkan closet, lantai dan dinding jamban maka tetap juga tercium bau dan terlihat tidak enak dipandang mata. Dan adanya anggapan masyarakat bahwa ketersediaan air bersih dengan kepemilikan jamban yang baik adalah sejalan.

Berdasarkan hasil penelitian variabel peran petugas kesehatan, diketahui sebagian besar responden mengatakan bahwa peran petugas kesehatan dalam kepemilikan jamban adalah kurang baik, dan hasil analisa data diperoleh bahwa tidak ada hubungan peran petugas kesehatan dengan kepemilikan jamban di Kampung Wainlabat Kota Sorong. Petugas kesehatan merupakan bagian dari mereka yang memiliki pengetahuan dan kemampuan dibidang kesehatan menyatakan diri bersedia untuk mengabdi pada bidang ilmunya untuk membantu pemerintah dalam upaya mencapai derajat kesehatan masyarakat yang maksimal. Petugas kesehatan memiliki peran sebagai sumber informasi 
atau pendidik, pembimbing, dan pemberi motivasi kepada masyarakat dalam rangka memeroleh dan meningkatkan status kesehatan keluarganya.

Penelitian menyatakan peran petugas kesehatan berhubungan dengan kepemilikan jamban yang memenuhi syarat ${ }^{(8,12)}$, pernyataan tersebut tidak sejalan dengan hasil penelitian ini, namun didukung oleh penelitian yang dilakukan di Kelurahan Alalak Utara Kota Banjarmasin yang mengatakan bahwa peran petugas tidak berhubungan dengan kepemilikan jamban, ${ }^{(13)}$ dan penelitian di Puskesmas Pancur yang menyimpulkan tidak terdapat hubungan peran petugas dengan kepemilikan jamban. ${ }^{(14)}$ didukung oleh penelitian yang dilakukan di Kelurahan Kampung Baru mengemukakan tidak ada hubungan peran petugas dengan kepemilikan jamban setelah stimulant diberikan. ${ }^{(15)}$

Jarak antara Kampung Wainlabat dengan Puskesmas cukup jauh, dapat ditempuh dengan menggunakan jalan darat maupun laut. Akses jalan darat menuju Kampung Wainlabat sangat tidak memadai apalagi ketika musim hujan. Mengingat jarak tempuh dari puskesmas menuju lokasi yang cukup jauh sehingga menjadi suatu kendala bagi petugas dalam memberikan penyuluhan dan pembimbingan masyarakat. Keterbatasan petugas kesehatan dalam memberikan pendampingan kepada masyarakat disambut kurang baik juga oleh masyarakat, karena ketika dilaksanakan penyuluhan dan pedampingan, masyarakat tidak secara keseluruhan memberikan waktu dan perhatian untuk materi yang akan diberikan. Selain alasan itu, mengingat status pekerjaan masyarakat yang mayoritas petani, buruh dan nelayan memberi petunjuk bahwa secara ekonomi masyarakat kurang mampu untuk menyediakan jamban yang sesuai dengan syarat kesehatan. Pendapatan yang diperoleh sehari-hari difokuskan pada kebutuhan hidup pokok seperti makanan dan sandang. Keadaan ini yang membuat masyarakat berasumsi bahwa yang penting menyediakan jamban baik di dalam rumah maupun di luar rumah, tanpa memperhatikan apakah jamban tersebut sudah memenuhi syarat kesehatan atau belum, dan ini tidak disadari masyarakat bahwa apabila perilaku ini memberikan dampak negatif bagi kesehatan keluarga dan hygiene lingkungan tinggalnya.

\section{KESIMPULAN}

Simpulan dalam penelitian ini adalah ada hubungan ketersediaan air bersih dengan kepemilikan jamban di Kampung Wainlabat Kabupaten Sorong dan tidak ada hubungan peran petugas kesehatan dengan kepemilikan jamban di Kampung Wainlabat Kabupaten Sorong. Saran bagi petugas kesehatan agar memberikan pembimbingan dan pendampingan masyarakat secara maksimal agar masyarakat menyediakan jamban untuk kebutuhan sehari-hari yang sesuai dengan ketentuan yang ada, dan kepada masyarakat Kampung Wainlabat agar menjalankan program pemerintah dengan baik sebagai salah satu upaya mencegahnya terjadinya penyakit menular akibat air limbah dan vektor untuk memeroleh status kesehatan yang baik melalui menyisihkan sebagian dari pendapatan agar mampu menyediakan jamban di dalam rumah tentu saja yang memenuhi syarat kesehatan.

\section{DAFTAR PUSTAKA}

1. Kemenkes RI. Sanitasi Total Berbasis Lingkungan. Jakarta; 2014. Report No.: No. 3 Tahun 2014.

2. Global Citizens for Human Rights. The Global Challenge for Government Transparency: The Sustainable Development Goals (SDG) 2030 Agenda [Internet]. 2016. Available from: https://worldtop20.org/global-movement?gclid=Cj0KCQjw6ZOIBhDdARIsAMf8YyFxR-

DfkMP4IXw9Zbsku34DO-_gGntnBc6YSNv3-1PWib9IW51zZWwaAnzkEALw_wcB

3. UNICEF Indonesia. Air, Sanitasi dan Kebersihan (WASH) [Internet]. 2020. Available from: https://www.unicef.org/indonesia/id/air-sanitasi-dan-kebersihan-wash

4. Kemenkes RI. Hasil Riset Kesehatan Dasar Tahun 2018. Kementrian Kesehat RI. 2018;53(9):1689-99.

5. Kemenkes RI. Profil Kesehatan RI 2019. Kementerian Kesehatan RI. 2020.

6. Lembaga Penerbit Badan Penelitian dan Pengembangan Kesehatan. Laporan Provinsi Papua Barat Riskesdas 2018. Ma; 2018. 412 p.

7. Putra GS, Selviana S. Faktor-Faktor Yang Berhubungan Dengan Kepemilikan Jamban Sehat Di Desa Empakan Kecamatan Kayan Hulu. J Kesmas (Kesehatan Masyarakat) Khatulistiwa. 2017;4(3):238.

8. Mukhlasin M, Solihudin EN. Kepemilikan Jamban Sehat Pada Masyarakat. Faletehan Heal J. 2020;7(03):119-23.

9. Mathofani PE, Annissa A, Metalia RP. Determinan Pemanfaatan Jamban Keluarga pada Keluarga. Faletehan Heal J. 2020;7(1):68-74. 
10. Theresiana Y, Triayana L, Clara S. Determinants of Healthy Latrines Ownership in Working Area at Public Health Center of Suak Tapeh in Banyuasin Regency South Sumatra 2019. 2020;25(Sicph 2019):268-76.

11. Wiya Elsa Fitri1 GEPS. Analisis Faktor Yang Berhubungan Dengan Rendahnya Kepemilikan Jamban Di Desa Baru Semerah Kecamatan Sitinjau Laut Kabupaten Kerinci. Tinj Sos Etika dan Huk Surrog mother di Indones. 2016;7(2):108-13.

12. Joseph WB, Warouw F. Faktor-Faktor Yang Berhubungan Dengan Tersedianya Jamban Keluarga Sehat Di Desa Tompaso Dua Kecamatan Tompaso Barat Kabupaten Minahasa. Kesmas. 2018;7(1).

13. Indah MF, Asrinawaty A, Nopeana NA. Analisis Kepemilikan Jamban Sehat pada masyarakat tepi sungai Di Kota Banjarmasin (Studi Di RT 01 Kelurahan Alalak Utara). An-Nadaa J Kesehat Masy. 2018;5(2):101.

14. Annissa A. Kepemilikan Jamban Di Kelurahan Kalanganyar Wilayah Kerja Puskesmas Pancur Tahun 2018. Faletehan Heal J. 2019;6(2):45-50.

15. Hayana H, Raviola R, Aryani E. Hubungan Cakupan Kepemilikan Jamban di Kelurahan Kampung Baru Kota Pekanbaru. J Kesehat Glob. 2020;3(1):9. 